\title{
IMPLEMENTASI JARINGAN SARAF TIRUAN METODE BACKPROPAGATION UNTUK MEMPREDIKSI JUMLAH NILAI EKSPOR DI PROVINSI NTB
}

\author{
(Implementation of Artificial Neural Network Algorithm Backpropagation Method \\ to Predict Amount of Export Value in the NTB Province) \\ Biondi Bagasta Wiko Putra*, Moh. Ali Albar dan Budi Irmawati \\ Program Studi Teknik Informatika, Fakultas Teknik, Universitas Mataram. \\ Jl. Majapahit 62, Mataram, Lombok, NTB-INDONESIA. \\ Email: siapaayo39@gmail.com,mohalialbar@unram.ac.id, budi-i@unram.ac.id
}

\begin{abstract}
This paper presents the application of the Backpropagation method of the Artificial Neural Network algorithm in the case study to predict the amount of export value in NTB province. This forecasting process uses two scenarios namely forecasting the total value of total exports in NTB province and forecasting the amount of export value based on commodity. The activation functions used are Sigmoid Binary and ReLU - Linear. Based on results of the system tests that have been carried out, Sigmoid Binary activation function shows that the best network architecture is 12-4-1, best learning rate is 0.3 and best error limit is 0.0015 , which in test phase produces an MSE value of 0.0161 and the MAPE value of 30.53\%, while ReLU-Linear activation function shows that the best network architecture is 12-5-1, best learning rate is 0.1 and best error limit is 0.0012 , which is at the test phase produce MSE value of 0.0309 and the MAPE value of 53.04\%. Because the MAPE value generated in the system testing using each activation function does not have a value of less than $20 \%$, the use of Backpropagation in the study is not suitable.

Keyword : Artificial Neural Network, Backpropagation, Value of Export, Forecasting, Activation Function
\end{abstract}

*Penulis Korespondensi

\section{Pendahuluan}

Provinsi NTB terkenal akan komoditi-komoditi ekspornya seperti gerabah, kerajinan buah kering, produk pertanian terutama jagung, mutiara dan konsentrat tembaga. Berdasarkan data Badan Pusat Statistik (BPS) provinsi NTB pada bulan Juni 2018, nilai ekspor Provinsi NTB sebesar US\$78.225.629 dan mengalami kenaikan sebesar $75.44 \%$ jika dibandingkan dengan nilai ekspor pada bulan Mei 2018 yang bernilai US\$ 44.588.299. Kenaikan nilai ekspor provinsi NTB yang sangat pesat ini menunjukan bahwa provinsi NTB berpotensi menjadi salah satu provinsi terbesar untuk menopang ekspor Indonesia [1].

Pada era digital saat ini perkembangan teknologi semakin pesat, dikarenakan orang-orang pada berlomba-lomba untuk menciptakan teknologi yang terbarukan. Salah satu contoh teknologi yang perkembangannya semakin pesat saat ini adalah kecerdasan buatan. Saat ini kecerdasan buatan sudah bisa diterapakan berbagai macam studi kasus terutama dalam studi kasus peramalan dengan berbagai macam algoritma yang digunakan. Salah satu algoritma yang biasa digunakan dalam studi kasus peramalan adalah algoritma jaringan saraf tiruan dengan metode backpropagation. Algoritma jaringan saraf tiruan dengan metode backpropagation diterapkan pada penelitian ini karena berdasarkan kemampuan belajar yang dimilikinya algoritma jaringan saraf tiruan dengan metode backpropagation dapat dilatih untuk mengenali, mempelajari dan menganalisa pola-pola data masa lalu, sehingga dengan pola data lalu tersebut dapat dicari suatu formula atau fungsi yang dapat menghubungkan pola data pada masa lalu dengan keluaran yang diinginkan pada saat ini, menghitung kesalahan pada keluaran yang didapatkan dan melakukan pembaharuan pola data pada setiap iterasi berdasarkan pelatihan data yang telah dilakukan untuk mengurangi tingkat kesalahan sehinnga dapat meningkatkan akurasi pada keluaran [2]. 
Data yang digunakan dalam penelitian ini yaitu jumlah nilai ekspor di provinsi NTB selama lima tahun mulai dari tahun 2014 sampai dengan tahun 2018 yang dicatat setiap bulannya oleh Dinas Perdagangan provinsi NTB, yang mana pada data tersebut terdapat data jumlah nilai ekspor per komoditi dan data jumlah nilai ekspor total dari semua komoditi setiap bulannya di provinsi NTB. Data jumlah nilai ekspor per komoditi digunakan untuk memprediksi nilai ekspor komoditi dan data jumlah nilai ekspor total dari semua komoditi digunakan untuk memprediksi jumlah nilai ekspor di provinsi NTB, sehingga pada penelitian ini terdapat dua skenario yaitu memprediksi jumlah nilai ekspor di provinsi NTB dan memprediksi jumlah nilai ekspor suatu komoditi setiap bulannya. Prediksi jumlah nilai ekspor ini dilakukan dengan tujuan untuk mengetahui seberapa akurat algoritma Jaringan Saraf Tiruan metode Backpropagation dalam meramalkan jumlah nilai ekspor di provinsi NTB dan hasil prediksi jumlah nilai ekspor ini diharapkan dapat bermanfaat bagi DInas Perdagangan provinsi NTB sebagai gambaran jumlah nilai ekspor di provinsi NTB untuk masa yang akan datang. Data Untuk skenario memprediksi jumlah nilai ekspor suatu komoditi hanya akan digunakan komoditi yang data jumlah nilai ekspornya lengkap dari tahun 2014 sampai tahun 2018 seperti Gerabah, Kerajinan Buah Kering, Mutiara dan Konsentrat Tembaga.

\section{TINJAUAN PUSTAKA}

Tulisan dari Saragih [3] yang berisi penelitian tentang akurasi dari algoritma jaringan saraf tiruan metode backpropagation dalam memprediksi jumlah nilai ekspor di provinsi Sumatera Utara dengan data dari tahun 2012 sampai tahun 2017. Penelitiannya menggunakan lima model arsitektur Jaringan Saraf Tiruan yakni model 4-5-1, 4-7-1, 4-9-1, 4-10-1 dan 4-111. Model terbaik dari ke lima model yang diuji adalah model 4-7-1 dengan menghasilkan tingkat akurasi $100 \%$, dengan waktu 27 detik. Batas error yang digunakan 0,001-0,05, dengan demikian maka model 4-7-1 cukup bagus untuk memprediksi Nilai Ekspor di Sumatera Utara, karena keakurasiannya mencapai $100 \%$.

Selain itu terdapat tulisan dari Anggriningrum [4] yang berisi penelitian tentang perbandingan antara algoritma ARIMA (Autoregressive Integrated Moving Average) dengan algoritma Jaringan Saraf Tiruan metode Backpropagation dalam memprediksi harga saham PT. Asuransi Bina Dana Arta (ABDA) Tbk. Arsitektur jaringan yang digunakan dengan algoritma jaringan saraf tiruan metode backpropagation sendiri adalah 1-1-1 sedangkan untuk algoritma ARIMA sendiri menggunakan model 1-1-0 (difference first-order autoregressive model). Berdasarkan hasil simulasi untuk algoritma Jaringan Saraf Tiruan metode Backpropagation sendiri menghasilkan nilai MSE (Mean Squared Error) dari tahap pelatihan sebesar 0,000206 dan nilai MSE untuk tahap pengujian sebesar 0,00140, sedangkan untuk algoritma ARIMA sendiri menghasilkan nilai MSE sebesar 0,01145. Karena selisih nilai MSE dari kedua metode tidak terlalu besar, maka kedua metode dapat digunakan untuk penelitian prediksi harga saham.

Selanjutnya terdapat tulisan Sutawinaya [5] yang berisi penelitian tentang perbandingan antara algoritma jaringan saraf tiruan metode Backpropagation dengan algoritma jaringan saraf tiruan metode ADALINE (Adaptive Linear Neuron) dalam meprediksi curah hujan di kota Denpasar. Arsitektur jaringan yang digunakan untuk masingmasing metode adalah 5-5-1. Berdasarkan hasil pengujian yang dilakukan sebanyak 1000 iterasi dihasilkan MSE sebesar 0,0019 untuk metode Backpropagation sedangkan untuk metode ADALINE dihasilkan MSE sebesar 0,0045, sehingga dapat disimpulkan bahwa metode Backpropagation lebih baik dari metode ADALINE dalam memprediksi curah hujan di kota Denpasar.

\section{Metode Penelitian}

Secara umum alur proses penelitian ini ditunjukan pada gambar berikut :

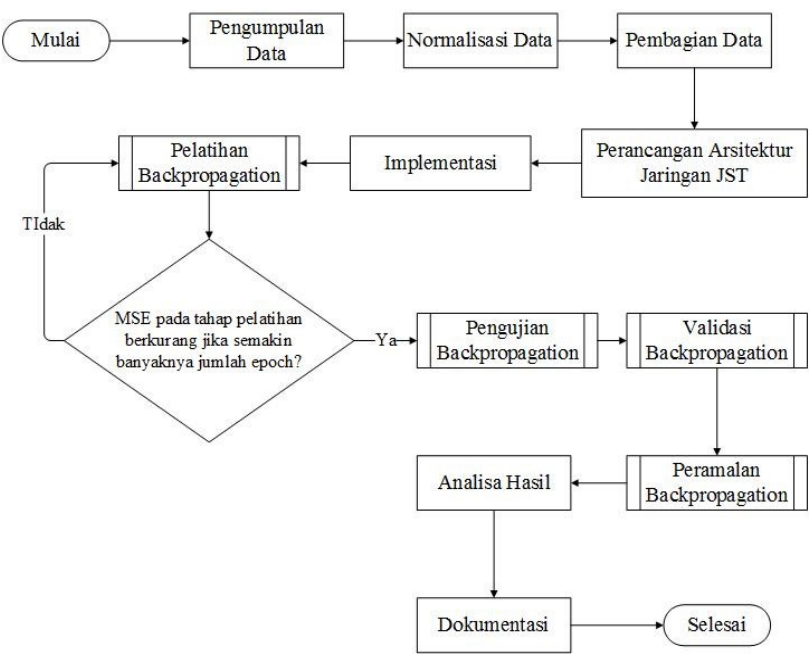

Gambar 1. Alur proses penelitian

Penjelasan setiap langkah alur proses penelitian ini adalah pada sub bab berikut.

\subsection{Pengumpulan Data}


Untuk mendapatkan data-data yang dibutuhkan dalam membantu berjalannya proses penelitian ini, dilakukan dengan cara studi literatur.

\subsection{Normalisasi Data}

Data yang bersifat masih mentah harus dinormalisasi terlebih dahulu untuk meningkatkan performa pada jaringan. Ketika dilakukan normalisasi, data bisa ditransformasikan ke interval anatara 0,1 sampai 0,9 . Proses normalisasi selalu menghasilkan data terkecil yang bernilai 0,1 dan untuk data yang terbesar selalu bernilai 0,9. Berikut ini merupakan rumus untuk melakukan normalisasi data :

$$
x^{\prime}=\frac{0,8(x-a)}{b-a}+0,1
$$

dimana :

$$
\begin{aligned}
& x^{\prime}: \text { Hasil normalisasi data. } \\
& x \text { : Data yang akan dinormalisasi. } \\
& a \text { : Data terkecil. } \\
& b \text { : Data terbesar. }
\end{aligned}
$$

\subsection{Pembagian Data}

Data yang diperoleh berupa data historis jumlah nilai ekspor di provinsi NTB yang didapatkan dari Dinas Perdagangan Provinsi NTB yang dicatat setiap bulannya dari tahun 2014 sampai dengan tahun 2018, akan dibagi menjadi empat bagian data yaitu data yang akan digunakan untuk tahap pelatihan, pengujian, validasi dan peramalan backpropagation.

\subsection{Perancangan Arsitektur Jaringan JST}

Pada tahap ini dirancang dan diteliti arsitektur jaringan yang akan digunakan pada tahap pelatihan, pengujian dan validasi untuk mencari yang mana merupakan arsitektur jaringan yang terbaik. Selanjutnya atsitektur jaringan yang terbaik tersebut akan digunakan untuk melakukan peramalan backpropagation. Adapun arsitektur jaringan yang digunakan dan diteliti yaitu arsitektur jaringan 12-11(12 buah neuron input layer, satu buah neuron hidden layer dan satu buah neuron output layer), 12-2-1, 12-31, 12-4-1 dan 12-5-1 dengan tujuan untuk mengetahui apakah jumlah neuron pada hidden layer sangat mempengaruhi keakurasian hasil peramalan. Jumlah hidden layer yang digunakan hanya satu saja karena penggunaan jaringan dengan lebih dari satu hidden layer dalam kasus peramalan tidak memberikan hasil peramalan yang berbeda jauh dengan menggunakan satu lapisan dan dengan semakin banyaknya hidden layer atau semakin banyaknya neuron yang digunakan juga akan memperlambat proses pelatihan [6].

\subsection{Implementasi}

Pada penelitian ini dilakukan pengimplementasian algoritma jaringan saraf tiruan metode backpropagation kedalam sebuah bahasa pemrograman. Bahasa pemrograman yang digunakan adalah Python versi 3.6 dengan library seperti Numpy, dan Pandas. Proses coding ini dilakukan dengan empat tahap yaitu coding untuk tahap pelatihan, pengujian, validasi dan peramalan. Pada tahap pelatihan dilakukan perulangan mulai dari fase propagasi maju hingga fase propagasi balik berdasarkan jumlah perulangan yang digunakan. Pada tahap pengujian dilakukan hanya pada fase propagasi maju saja karena hanya mengujikan bobot yang dihasilkan pada tahap pelatihan. Pada tahap validasi dilakukan percobaan untuk meramalkan jumlah nilai ekspor di provinsi NTB pada tahun 2018, meskipun data jumlah nilai ekspor di provinsi NTB sudah ada. Pada tahap peramalan dilakukan peramalan jumlah nilai ekspor di provinsi NTB untuk masa yang akan datang yaitu pada tahun 2019 dan seterusnya. Fungsi aktivasi yang digunakan adalah Sigmoid Biner, ReLU dan Linear. Berikut ini merupakan rumus untuk masing - masing fungsi aktivasi :

\section{Sigmoid Biner}

$$
f(x)=\frac{1}{1+e^{-x}}
$$

dimana:

$y=$ Keluaran pada jaringan

$x=$ Hasil perkalian bobot dan input ditambah bias.

$e=$ Bilangan eksponensial.

\section{ReLU (Rectified Linear Unit)}

$$
f(x)=\max (0, x)
$$

dimana :

$x=$ Hasil perkalian bobot dan input ditambah bias. max $=$ Nilai maksimum

3. Linear

$$
y=x
$$

dimana :

$x=$ Hasil perkalian bobot dan input ditambah bias.

Berikut ini merupakan algoritma pelatihan Backpropagation [7] :

Langkah 1 : Definisikan pola data yang digunakan sebagai masukan dan target pelatihan.

Langkah 2 : Inisialisasi nilai bobot awal dan bias dengan bilangan acak dengan rentang $[0,1]$. 
Langkah 3 : Tentukan jumlah epoch, target error, dan learning rate yang akan digunakan. Epoch adalah proses perhitungan pelatihan Backpropagation mulai dari tahap propagasi maju (forward pass) hingga propagasi balik (backward pass). Satu epoch berarti proses perhitungan hanya pada tahap propagasi maju sampai propagasi balik saja, sedangkan dua epoch berarti proses perhitungan mulai dari tahap propagasi maju hingga propagasi balik, setelah itu dilanjutkan lagi tahap propagasi maju hingga propagasi balik dengan menggunakan bobot baru yang didapatkan pada epoch sebelumnya sehingga terhitung terdapat dua epoch. Begitu juga seterusnya untuk epoch yang lebih tinggi.

Langkah 4 : Kerjakan langkah-langkah selanjutnya selama epoch sudah mencapai target jumlah epoch dan nilai error sudah mencapai nilai batas error yang digunakan. Target error adalah nilai error yang diinginkan untuk menghentikan proses pelatihan. Jika target error sudah memenuhi walaupun epoch belum selesai, maka proses pelatihan tetap bisa dihentikan.

\section{Fase I : Propagasi Maju.}

Langkah 5 : Jumlahkan semua sinyal dari neuron input layer yang masuk ke neuron hidden layer (znet_j) $\left(\mathrm{x}_{\mathrm{i}}\right.$, $i=1,2,3, \ldots, n)\left(v_{j}, j=1,2,3, \ldots, n\right)$.

$$
z_{-} n e t_{j}=v_{j 0}+\sum_{i=1}^{n} x_{i} v_{j i}
$$

dimana :

$z_{-} n e t_{j}$ : Jumlah sinyal neuron input layer yang masuk menuju neuron hidden layer.

$x_{i}$ : Pola masukan.

$v_{j}$ : Bobot sinyal dari neuron input layer yang menuju ke neuron hidden layer.

$v_{j 0}$ : Bobot bias hidden layer.

Selanjutnya hitung output masing-masing neuron pada hidden layer dengan menggunakan fungsi aktivasi, misalnya dengan fungsi aktivasi sigmoid biner.

dimana:

$$
z_{j}=f\left(z_{n e t_{j}}\right)=\frac{1}{1+e^{-z_{n e t}}}
$$

$z_{j}$ : Keluaran sinyal neuron hidden layer.

$e$ : Bilangan exponensial.

Langkah 6 : Jumlahkan semua output sinyal dari neuron hidden layer yang menuju ke neuron output layer (y_net $\left.{ }_{k}\right)(k=1,2, \ldots, m)$. dimana:

$$
y_{-} n e t_{k}=w_{k 0}+\sum_{j=1}^{p} z_{j} w_{k j}
$$

$y_{-} n t_{k}$ : Jumlah sinyal yang masuk menuju neuron output layer.

$w_{k j}$ : Bobot sinyal dari neuron hidden layer yang masuk ke neuron output layer.

$w_{k 0}$ : Bobot bias output layer.

Lalu gunakan fungsi aktivasi untuk menghitung output pada jaringan.

$$
y_{k}=f\left(y_{-} n e t_{k}\right)=\frac{1}{1+e^{-y_{-} n e t_{k}}}
$$

dimana:

$y_{k}$ : Keluaran pada jaringan.

\section{Fase II : Propagasi Mundur.}

Langkah 7 : Hitung faktor kesalahan $(\delta)$ pada output jaringan $y_{k}(k=1,2, \ldots, m)$.

$$
\delta_{k}=\left(t_{k}-y_{k}\right) y_{k}\left(1-y_{k}\right)
$$

dimana:

$\delta_{k}$ : Faktor kesalahan output jaringan.

$t_{k}$ : Target pada pola.

Hitung suku perubahan bobot $w_{k j}$ (yang akan digunakan untuk memperbaharui bobot $w_{k j}$ ) dengan learning rate $(\alpha)$.

$$
\Delta w_{k j}=\alpha \delta_{k} z_{j}
$$

dimana:

$\Delta w_{k j}=$ Suku perubahan bobot $w_{k j}$.

Hitung suku perubahan bobot bias pada output layer dengan learning rate $(\alpha)$.

dimana:

$$
\Delta w_{b}=\alpha \delta_{k} x_{b}
$$

$\Delta w_{b}=$ Suku perubahan bobot bias pada output layer.

$x_{b}=$ Nilai input dummy (biasanya $=1$ )

Langkah 8 : Hitung faktor kesalahan $(\delta)$ sinyal yang masuk menuju neuron pada hidden layer berdasarkan faktor kesalahan disetiap neuron pada hidden layer $\left(\mathrm{z}_{\mathrm{j}}\right)$ dengan output jaringan $\left(\delta_{k}\right)$.

$$
\delta_{n e t_{j}}=\sum_{k=1}^{m} \delta_{k} w_{k j}
$$

dimana:

$\delta \delta_{-}$et $_{j}$ : Faktor kesalahan sinyal yang masuk ke neuron hidden layer. 
Kalikan nilai $\delta \_n e t_{j}$ dengan turunan dari fungsi aktivasinya untuk mencari faktor kesalahan setiap neuron hidden layer:

$$
\delta_{j}=\delta_{-} n e t_{j} z_{j}\left(1-z_{j}\right)
$$

dimana:

$\delta_{\mathrm{j}}$ : Faktor kesalahan neuron hidden layer.

Hitung suku perubahan bobot $\mathrm{v}_{\mathrm{ji}}$ (yang akan dipakai nanti untuk memperbaharui bobot $\mathrm{v}_{\mathrm{ji}}$ ).

$$
\Delta v_{j i}=\alpha \delta_{j} x_{i}
$$

dimana:

$\Delta v_{j i}=$ Suku perubahan bobot sinyal neuron input layer yang menuju ke neuron hidden layer.

Hitung suku perubahan bobot bias pada hidden layer

$$
\Delta v_{b}=\alpha \delta_{j} x_{b}
$$

dimana:

$\Delta v_{b}=$ Suku perubahan bobot bias pada hidden layer.

$x_{b}=$ Nilai input dummy (biasanya bernilai $=1$ )

Fase III : Perubahan bobot.

Langkah 9 : Hitung semua perubahan bobot garis.

- Hitung perubahan bobot sinyal neuron hidden layer yang menuju ke neuron output layer:

$$
w_{k j}(\text { baru })=w_{k j}(\operatorname{lama})+\Delta w_{k j}
$$

- Hitung perubahan bobot bias pada output layer :

$$
w_{k} 0(\text { baru })=w_{k} 0(\text { lama })+\Delta w_{b}
$$

- Hitung perubahan bobot garis dari neuron input layer ke neuron hidden layer:

$$
v_{j i}(\text { baru })=v_{j i}(\operatorname{lama})+\Delta v_{j i}
$$

- Hitung perubahan bobot bias pada output layer:

$$
v_{j 0}(\text { baru })=v_{j 0}(\operatorname{lama})+\Delta v_{b}
$$

- Setelah dilakukan pembaruan bobot, selanjutnya dilakukan perhitungan nilai MSE (Mean Square Error) dengan menggunakan rumus berikut :

$$
M S E=\frac{1}{k} \sum_{k=1}^{n}\left(y_{k}-t_{k}\right)^{2}
$$

dimana:

$$
\begin{aligned}
& n: \text { jumlah data; } t_{k}: \text { nilai target data } \\
& y_{k} \text { : nilai output data }
\end{aligned}
$$

- Selanjutnya hitung nilai MAPE (Mean Absolute Percent Error) untuk menghitung rata-rata persentase error hasil peramalan dengan rumus :

$$
M A P E=\frac{1}{n} \sum_{k=1}^{n} \frac{|t k-y k|}{t k} \times 100 \%
$$

dimana:

$n$ : jumlah data $\quad t_{k}$ : nilai target data

$y_{k}$ : nilai output data

Langkah 10: Uji kondisi berhenti (akhir iterasi) dengan melihat apakah target epoch dan target error telah tercapai..

\subsection{Analisa Hasil}

Pada Tahap ini dilakukan analisa hasil implentasi coding metode Backpropagation yang telah dibuat seperti menganalisa variabel yang terbaik dan analisa akurasi hasil peramalan.

\subsection{Dokumentasi}

Pada tahap ini dilakukan pendokumentasian hasil analisa coding kedalam bentuk laporan maupun jurnal.

\section{HaSil dan PEMBahasan}

\subsection{Perancangan dan Pembangunan Sistem}

Sistem ini dibangun dengan menggunakan bahasa pemrograman python versi 3.7.3. Adapun library yang digunakan seperti Numpy, Pandas dan Matplotlib. Pada sistem ini terdapat empat buah file ber-format .py untuk tahap pelatihan, pengujian, validasi dan peramalan Backpropagation. Selanjutnya terdapat dua buah file ber-format .csv yaitu dataset.csv membuat dataset dan bobot_pengujian.csv untuk menyimpan bobot hasil pelatihan data dan digunakan pada tahap pengujian, validasi dan peramalan.

\subsection{Pengujian Sistem}

Pengujian sistem ini dilakukan dengan tujuan untuk menguji sistem yang telah dibangun dengan cara melakukan analisis terhadap hasil, nilai MSE dan nilai MAPE dari proses pelatihan, pengujian dan validasi Backpropagation dengan menggunakan berbagai macam jumlah data pelatihan - pengujian, jumlah neuron pada hidden layer dan beragan nilai learning rate. Pengujian sistem ini dilakukan dengan menggunakan dua skenario yaitu dengan menggunakan fungsi aktivasi Sigmoid Biner pada hidden layer dan output layer dan dengan menggunakan fungsi aktivasi ReLU pada hidden layer dan Linear pada output layer.

\subsubsection{Pengujian Sistem dengan Fungsi Aktivasi Sigmoid Biner}

Berikut ini merupakan pengujian sistem dengan menggunakan fungsi aktivasi Sigmoid Biner. 


\subsubsection{Pengujian Pengaruh Pembagian Jumlah Data Pelatihan - Pengujian}

Pengujian ini bertujuan untuk mengetahui pembagian jumlah data pelatihan dan pengujian yang mana sebaiknya digunakan pada peramalan ini. Arsitektur jaringan yang digunakan adalah 12-3-1, inisialisasi bobot awal $=[-0,1,0,1]$, batas error $=0,0015$ dan learning rate $=0.3$. Pada Tabel I merupakan hasil pengujian pengaruh pembagian jumlah data pelatihan dan pengujian :

tabel I. hasil Pengujian Pengaruh Jumlah Pembagian Data Pelatihan - Pengujian

\begin{tabular}{|c|c|c|c|c|}
\hline No & $\begin{array}{l}\text { Data } \\
\text { Pelatihan } \\
\text { - } \\
\text { Pengujian }\end{array}$ & Epoch & $\begin{array}{l}\text { MSE } \\
\text { Pengujian }\end{array}$ & $\begin{array}{l}\text { MAPE } \\
\text { Pengujian }\end{array}$ \\
\hline 1 & $\begin{array}{l}(2014- \\
2016), \\
(2016- \\
2017)\end{array}$ & 5190 & 0,1249 & $133,34 \%$ \\
\hline 2 & $\begin{array}{l}\text { (2014- } \\
2015), \\
(2016- \\
2017)\end{array}$ & 4890 & 0,1294 & $99,27 \%$ \\
\hline 3 & $\begin{array}{l}\text { (2014- } \\
2016), \\
(2015- \\
2017)\end{array}$ & 5190 & 0,0627 & $69,02 \%$ \\
\hline
\end{tabular}

Berdasarkan TABEL I bisa dilihat bahwa pembagian data (2014-2016) untuk pelatihan dan (2015-2017) untuk pengujian menghasilkan nilai MSE dan MAPE terendah pada tahap pengujian sehingga dapat disimpulkan bahwa pembagian data (2014-2016) untuk pelatihan dan (2015-2017) merupakan yang terbaik.

\subsubsection{Pengujian Pengaruh Jumlah Neuron Hidden layer}

Pengujian ini bertujuan untuk mencari arsitektur jaringan yang terbaik berdasarkan nilai MSE dan MAPE yang dihasilkan pada tahap pengujian. Pengujian pengaruh jumlah neuron hidden layer ini dilakukan dengan menggunakan pembagian data pelatihan = (2014-2016), pengujian $=(2015-2017)$, jumlah neuron hidden layer dari satu sampai dengan lima buah, inisialisasi bobot awal dengan rentang $[-0,1,0,1]$, learning rate $=0,3$, batas error $=0,0015$ dan epoch $=$ 20000. Pada TABEL II merupakan hasil pengujian pengaruh jumlah neuron pada hidden layer terhadap hasil pelatihan dan pengujian.
tABEl II. Hasil Pengujian Pengaruh Jumlah Neuron pada HIDDEN LAYER

\begin{tabular}{|l|l|l|l|l|}
\hline No & $\begin{array}{l}\text { Arsitektur } \\
\text { Jaringan }\end{array}$ & Epoch & $\begin{array}{l}\text { MSE } \\
\text { Pengujian }\end{array}$ & $\begin{array}{l}\text { MAPE } \\
\text { Pengujian }\end{array}$ \\
\hline 1 & $12-1-1$ & 20000 & 0,0526 & $86,13 \%$ \\
\hline 2 & $12-2-1$ & 20000 & 0,0523 & $67,33 \%$ \\
\hline 3 & $12-3-1$ & 5190 & 0,0627 & $69,02 \%$ \\
\hline 4 & $12-4-1$ & 4440 & 0,0161 & $30.53 \%$ \\
\hline 5 & $12-5-1$ & 4940 & 0,0269 & $50.22 \%$ \\
\hline
\end{tabular}

Berdasarkan Tabel II dapat disimpulkan bahwa terdapat dua arsitektur jaringan terbaik yaitu arsitektur 12-4-1 karena menghasilkan nilai MSE dan MAPE terendah pada tahap pengujian dengan epoch = 4390. Berdasarkan Tabel II juga dapat bisa dilihat bahwa arsitektur jaringan 12-1-1 dan arsitektur 12-2-1 belum mampu mencapai target error meskipun pada epoch $=20000$. Hal ini menunjukkan bahwa jumlah neuron hidden layer terlalu sedikit tidak baik, karena dapat memperlambat proses pembelajaran.

\subsubsection{Pengujian Pengaruh Nilai Learning Rate}

Pengujian ini bertujuan untuk mengetahui nilai learning rate berapa merupakan yang terbaik dengan menghasilkan nilai MSE dan MAPE terendah pada tahap pengujian. Pada pengujian learning rate ini dilakukan dengan nilai learning rate sebesar $(0,1,0,2$, $0,3,0,4,0,5,0,6,0,7,0,8$ dan 0,9) dengan arsitektur jaringan 12-4-1, inisialisasi bobot awal dengan rentang $[-0,1,0,1]$, batas error $=0,0015$ dan jumlah epoch $=$ 20000. Pada Tabel III merupakan hasil pengujian pengaruh learning rate.

TABEL III. Hasil Pengujian Pengaruh Nilai Learning Rate

\begin{tabular}{|l|l|l|l|l|}
\hline No & $\begin{array}{l}\text { Learning } \\
\text { Rate }\end{array}$ & Epoch & $\begin{array}{l}\text { MSE } \\
\text { Pengujian }\end{array}$ & $\begin{array}{l}\text { MAPE } \\
\text { Pengujian }\end{array}$ \\
\hline 1 & 0,1 & 14540 & 0,0186 & $35,14 \%$ \\
\hline 2 & 0,2 & 6950 & 0,0164 & $31,28 \%$ \\
\hline 3 & 0,3 & 4440 & 0,0161 & $30,53 \%$ \\
\hline 4 & 0,4 & 3320 & 0,0164 & $29.54 \%$ \\
\hline 5 & 0,5 & 2660 & 0,0177 & $25,90 \%$ \\
\hline 6 & 0,6 & 2320 & 0,0259 & $34,49 \%$ \\
\hline 7 & 0,7 & 2070 & 0,0301 & $39,45 \%$ \\
\hline 8 & 0,8 & 1900 & 0,0335 & $43,35 \%$ \\
\hline 9 & 0,9 & 2020 & 0,0269 & $42,22 \%$ \\
\hline
\end{tabular}

Berdasarkan Tabel III bisa dilihat bahwa learning rate $=0,3$ menghasilkan nilai MSE yang terkecil, sedangkan learning rate $=0,5$ menghasilkan nilai MAPE terkecil. Berdasarkan hasil penelitian Hyndman[8], nilai MAPE lebih bagus digunakan jika semua data postitif dan jauh lebih besar dari nol, sedangkan pada penelitian ini dilakukan normalisasi data dengan interval antara $[0,1,0,9]$ yang mana nilainya mendekati 
nol dan range keluarannya berada pada rentang $[0,1]$, sehingga berpatokan berdasarkan nilai MAPE kurang cocok pada pengujian ini dan lebih bagus untuk menggunakan nilai MSE sebagai patokan hasil akurasi pengujian data. Berdasarkan hal tersebut, maka nilai learning rate $=0,3$ akan digunakan pada tahap validasi dan peramalan. Pada Gambar 2 merupakan grafik perbandingan hasil pengujian learning rate sesuai dengan hasil pengujian pada Tabel III.

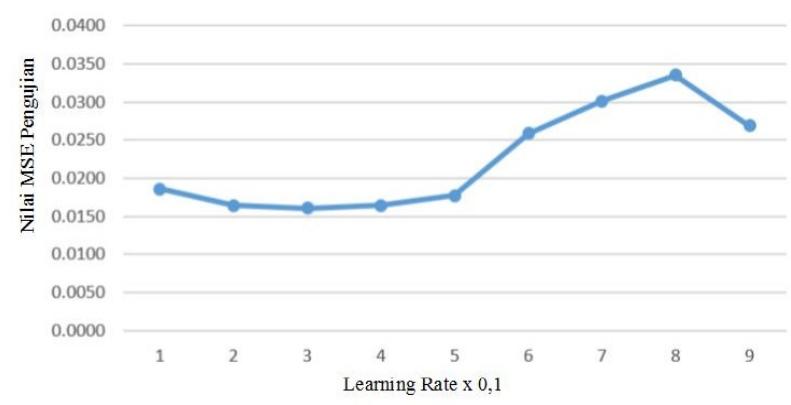

Gambar 2. Grafik hasil pengujian pengaruh nilai learning rate

\subsubsection{Pengujian Pengaruh Nilai Batas Error}

Pengujian ini bertujuan untuk mencari nilai batas error yang terbaik dengan menghasilkan nilai MSE dan MAPE terendah pada tahap pengujian. Pengujian pengaruh nilai batas error ini dilakukan dengan arsitektur jaringan 12-4-1, learning rate $=0,3$ dan nilai batas error dari 0,0001 sampai dengan 0,0015. Pada Tabel IV merupakan hasil pengujian pengaruh nilai batas error.

TABEL IV. HASIL PengujIAN PEngaruh Nilai Batas ERROR

\begin{tabular}{|l|l|l|l|l|}
\hline No & $\begin{array}{l}\text { Batas } \\
\text { Error }\end{array}$ & Epoch & $\begin{array}{l}\text { MSE } \\
\text { Pengujian }\end{array}$ & $\begin{array}{l}\text { MAPE } \\
\text { Pengujian }\end{array}$ \\
\hline 1 & 0,0001 & 7840 & 0,0217 & $34,55 \%$ \\
\hline 2 & 0,0002 & 7050 & 0,0202 & $33,43 \%$ \\
\hline 3 & 0,0003 & 6560 & 0,0193 & $32,67 \%$ \\
\hline 4 & 0,0004 & 6190 & 0,0186 & $32,18 \%$ \\
\hline 5 & 0,0005 & 5900 & 0,0181 & $31,77 \%$ \\
\hline 6 & 0,0006 & 5660 & 0,0178 & $31,53 \%$ \\
\hline 7 & 0,0007 & 5450 & 0,0174 & $31,26 \%$ \\
\hline 8 & 0,0008 & 5270 & 0,0172 & $31,12 \%$ \\
\hline 9 & 0,0009 & 5110 & 0,0170 & $31,00 \%$ \\
\hline 10 & 0,0010 & 4970 & 0,0168 & $30,87 \%$ \\
\hline 11 & 0,0011 & 4840 & 0,0166 & $30,75 \%$ \\
\hline 12 & 0,0012 & 4730 & 0,0165 & $30,73 \%$ \\
\hline 13 & 0,0013 & 4620 & 0,0163 & $30,64 \%$ \\
\hline 14 & 0,0014 & 4530 & 0,0162 & $30,55 \%$ \\
\hline 15 & 0,0015 & 4440 & 0,0161 & $30.53 \%$ \\
\hline
\end{tabular}

Berdasarkan Tabel IV dapat disimpulkan bahwa nilai batas error $=0,0015$ adalah yang terbaik karena menghasilkan nilai MSE dan MAPE terendah pada tahap pengujian. Pada Gambar 3 merupakan grafik hasil pengujian pengaruh nilai batas error.

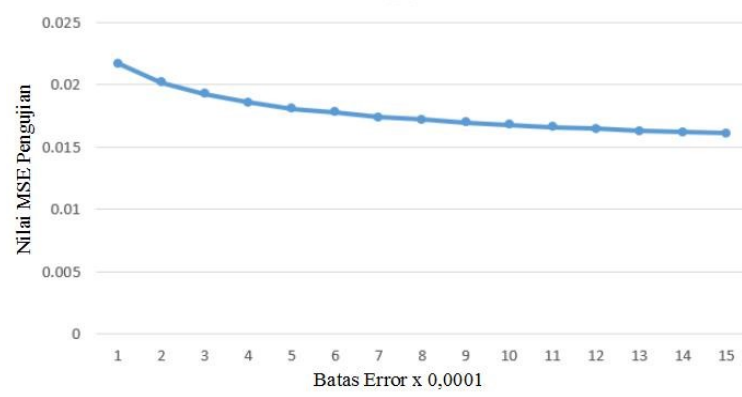

Gambar 3. Grafik hasil pengujian pengaruh nilai batas error

\subsubsection{Validasi Backpropagation}

Pada tahap ini dilakukan peramalan terhadap data yang ada namun tidak digunakan pada tahap pelatihan dan pengujian yaitu data pada tahun 2018, dengan menggunakan nilai variabel berdasarkan hasil dari pengujian sistem yang telah dilakukan. Pada Tabel V merupakan hasil dari tahap validasi Backpropagation dengan meramalkan data pada tahun 2018 yang mana tersebut sudah ada.

TABEL V. HASIL DARI TAHAP VALIDASI BACKPROPAGATION DENGAN MERAMALKAN DATA PADA TAHUN 2018

\begin{tabular}{|l|l|l|}
\hline No & Data Aktural 2018 & Prediksi 2018 \\
\hline 1 & 55.623 .525 & 185.620 .016 \\
\hline 2 & 49.500 & -18.639 .762 \\
\hline 3 & 37.925 .880 & 77.668 .640 \\
\hline 4 & 40.510 .456 & 169.522 .848 \\
\hline 5 & 41.392 .078 & 35.958 .744 \\
\hline 6 & 73.611 .411 & 137.864 .880 \\
\hline 7 & 36.691 .259 & 219.132 .336 \\
\hline 8 & 27.526 .174 & -15.101 .917 \\
\hline 9 & 39.206 .347 & 84.789 .128 \\
\hline 10 & 733.763 & 179.705 .168 \\
\hline 11 & 29.533 .386 & 26.020 .544 \\
\hline 12 & 29.452 .168 & 256.743 .264 \\
\hline
\end{tabular}

Berdasarkan Tabel $\mathrm{V}$ bisa dilihat bahwa terdapat hasil peramalan yang bernilai negatif atau hasil peramalan yang lebih kecil dari 0,1 ketika masih dinormalisasi. Hal ini disebabkan karena tidak stabilnya data jumlah nilai ekspor di provinsi NTB sehingga membutuhkan proses pelatihan yang sangat lama pada epoch yang besar. Dengan semakin besarnya jumlah epoch tersebut dapat menyebabkan terjadinya vanishing gradient dan nilai bobot yang dihasilkan terlalu besar pada fungsi aktivasi Sigmoid Biner. Vanishing gradient adalah terlalu kecilnya nilai 
gradient yang dihasilkan ketika proses propagasi balik sehingga terjadi pembaruan bobot yang sangat kecil [9]. Dengan terjadinya vanihsing gradient ini dapat menimbulkan ketidak seimbangan bobot yang dihasilkan ketika tahap propagasi balik, seperti terdapat sebagian bobot yang perubahannya sangat besar dan terdapat sebagian bobot yang perubahannya sangat kecil sehingga menyebabkan terjadinya ketidak seimbangan. Ketika bobot yang dihasilkan dari banyaknya epoch dan terdapat vanishing gradient ini diterapkan pada tahap peramalan memungkinkan terjadinya hasil peramalan yang bernilai negatif. Pada Gambar 4 merupakan pola data jumlah nilai ekspor di provinsi NTB yang memungkinkan terjadinya hasil validasi yang bernilai negatif.

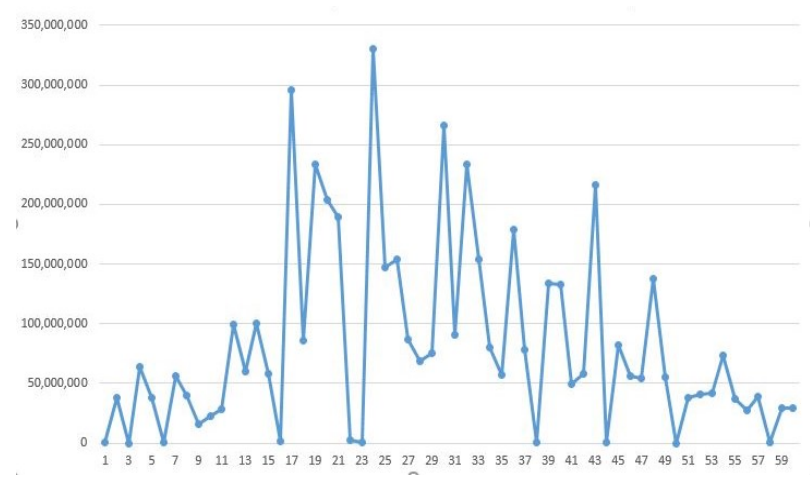

Gambar 4. Pola data jumlah nilai ekspor di provinsi NTB

Berdasarkan grafik pada Gambar 4, dapat dilihat bahwa pola data jumlah nilai ekspor di provinsi NTB sangat tidak stabil sehingga memungkinkan hasil peramalan yang bernilai negatif.

\subsubsection{Pengujian Sistem dengan Fungsi Aktivasi \\ ReLU - Linear}

Pada skenario ini dilakukan pengujian sistem dengan menggunakan fungsi aktivasi ReLU pada hidden layer dan Linear pada output layer. Berikut ini merupakan pengujian sistem dengan menggunakan fungsi aktivasi ReLU - Linear.

\subsubsection{Pengujian Pengaruh Jumlah Neuron pada Hidden layer}

Pengujian ini bertujuan untuk mencari arsitektur jaringan terbaik dengan menggunakan fungsi aktivasi ReLU - Linear. Pengujian ini dilakukan dengan cara membandingkan jumlah neuron pada hidden layer dari satu buah sampai dengan lima buah. Pada Tabel VI merupakan hasil pengujian pengaruh jumlah neuron pada hidden layer dengan menggunakan epoch = 20000 , learning rate $=0,1$ dan batas error $=0,0015$.
TABEL VI. Hasil PenguJian Pengaruh Jumlah NEURON PADA HIDDEN LAYER

\begin{tabular}{|l|l|l|l|l|}
\hline No & $\begin{array}{l}\text { Arsitektur } \\
\text { Jaringan }\end{array}$ & Epoch & $\begin{array}{l}\text { MSE } \\
\text { Pengujian }\end{array}$ & $\begin{array}{l}\text { MAPE } \\
\text { Pengujian }\end{array}$ \\
\hline 1 & $12-1-1$ & 20000 & 0,0320 & $66.58 \%$ \\
\hline 2 & $12-2-1$ & 20000 & 0,0016 & $38,94 \%$ \\
\hline 3 & $12-3-1$ & 2000 & 0,0014 & $122,20 \%$ \\
\hline 4 & $12-4-1$ & 400 & 0,0008 & $63,36 \%$ \\
\hline 5 & $12-5-1$ & 450 & 0,0008 & $53,07 \%$ \\
\hline
\end{tabular}

Berdasarkan Tabel VI dapat disimpulkan bahwa arsitektur jaringan 12-5-1 merupakan yang terbaik karena menghasilkan nilai MSE dan MAPE terkecil pada tahap pengujian.

\subsubsection{Pengujian Nilai Learning Rate}

Pengujian ini bertujuan untuk mengetahui nilai learning rate yang terbaik dengan menggunakan fungsi aktivasi ReLU dan Linear. Pengujian ini dilakukan dengan menggunakan arsitektur jaringan = 12-5-1, batas error $=0,0008$, epoch $=20000$ dan nilai learning rate yang digunakan mulai dari 0,1 sampai dengan 0,9 . Pada Tabel VII merupakan hasil pengujian pengaruh nilai learning rate pada fungsi aktivasi ReLU dan Linear.

TABEL VII. Hasil Pengujian Pengaruh Nilai Learning Rate

\begin{tabular}{|l|l|l|l|l|}
\hline No & $\begin{array}{l}\text { Learning } \\
\text { Rate }\end{array}$ & Epoch & $\begin{array}{l}\text { MSE } \\
\text { Pengujian }\end{array}$ & $\begin{array}{l}\text { MAPE } \\
\text { Pengujian }\end{array}$ \\
\hline 1 & 0,1 & 450 & 0,0316 & $53,07 \%$ \\
\hline 2 & 0,2 & 20000 & 0,0448 & $72,48 \%$ \\
\hline 3 & 0,3 & 20000 & 0,0498 & $68,06 \%$ \\
\hline 4 & 0,4 & 20000 & 0,0482 & $78,16 \%$ \\
\hline 5 & 0,5 & 20000 & 0,0449 & $81,63 \%$ \\
\hline 6 & 0,6 & 20000 & 0,1090 & $117,72 \%$ \\
\hline 7 & 0,7 & 20000 & 0,0479 & $84,22 \%$ \\
\hline 8 & 0,8 & 20000 & 0,0592 & $73,86 \%$ \\
\hline 9 & 0,9 & 20000 & 0,0469 & $85,37 \%$ \\
\hline
\end{tabular}

Berdasarkan Tabel $\mathrm{V}$ dapat disimpulkan bahwa nilai learning rate $=0,1$ adalah yang terbaik dengan menggunakan fungsi aktivasi ReLU - Linear, karena menghasilkan nilai MSE dan MAPE terkecil pada tahap pengujian. Berdasarkan Tabel V juga bisa dilihat bahwa nilai learning rate diatas 0,1 belum mampu mencapai target error meskipun sudah berada pada epoch 20000. Hal ini menunjukkan bahwa jika ingin menggunakan fungsi aktivasi ReLU dan Linear, harus hati - hati dalam menetapkan nilai learning rate karena jika kebesaran akan menyebabkan "dying ReLU” target error menjadi tidak tercapai [10]. Pada Gambar 6 merupakan grafik hasil pengujian pengaruh nilai learning rate terhadap nilai MSE yang dihasilkan pada tahap pengujian dengan menggunakan fungsi aktivasi ReLU - Linear. 


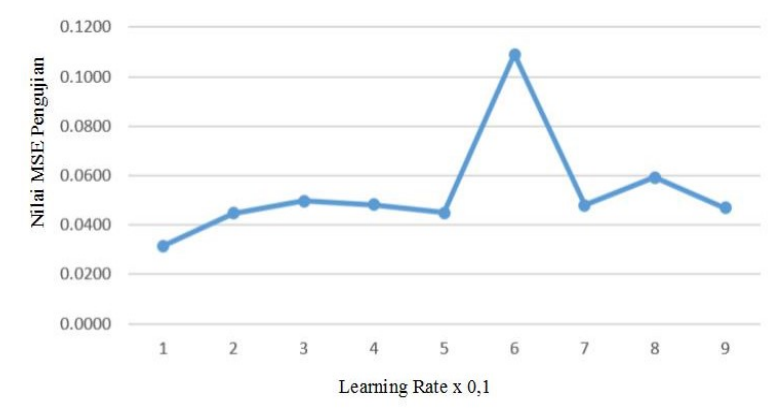

Gambar 5. Grafik hasil pengujian pengaruh nilai learning rate dengan fungsi aktivasi ReLU - Linear.

\subsubsection{Pengujian Pengaruh Nilai Batas Error}

Pengujian ini bertujuan untuk mengetahui nilai batas error berapa yang terbaik dengan menggunakan fungsi aktivasi ReLU - Linear. Pengujian pengaruh nilai batas error dilakukan dengan menggunakan arsitektur jaringan 12-5-1, learning rate = 0,1 dan batas error dari 0,0001 sampai dengan 0,0015. Pada Tabel VIII merupakan hasil pengujian pengaruh nilai batas error dengan menggunakan fungsi aktivasi ReLU - Linear.

TABEL VIII. HASIL PENGUJIAN NILAI BATAS ERROR PADA FUNGSI AKTIVASI RELU - LINEAR

\begin{tabular}{|l|l|l|l|l|}
\hline No & $\begin{array}{l}\text { Batas } \\
\text { Error }\end{array}$ & Epoch & $\begin{array}{l}\text { MSE } \\
\text { Pengujian }\end{array}$ & $\begin{array}{l}\text { MAPE } \\
\text { Pengujian }\end{array}$ \\
\hline 1 & 0,0001 & 604 & 0,0364 & $54,16 \%$ \\
\hline 2 & 0,0002 & 557 & 0,0347 & $53,59 \%$ \\
\hline 3 & 0,0003 & 524 & 0,0342 & $53,71 \%$ \\
\hline 4 & 0,0004 & 501 & 0,0331 & $53,25 \%$ \\
\hline 5 & 0,0005 & 481 & 0,0325 & $53,10 \%$ \\
\hline 6 & 0,0006 & 465 & 0,0317 & $53,08 \%$ \\
\hline 7 & 0,0007 & 453 & 0,0324 & $53,65 \%$ \\
\hline 8 & 0,0008 & 442 & 0,0312 & $53,06 \%$ \\
\hline 9 & 0,0009 & 432 & 0,0318 & $53,47 \%$ \\
\hline 10 & 0,0010 & 428 & 0,0314 & $53,35 \%$ \\
\hline 11 & 0,0011 & 421 & 0,0316 & $53,47 \%$ \\
\hline 12 & 0,0012 & 416 & 0,0309 & $53,04 \%$ \\
\hline 13 & 0,0013 & 410 & 0,0311 & $53,59 \%$ \\
\hline 14 & 0,0014 & 406 & 0,0311 & $53,49 \%$ \\
\hline 15 & 0,0015 & 404 & 0,0314 & $54,48 \%$ \\
\hline
\end{tabular}

Berdasarkan Tabel VIII dapat disimpulkan bahwa nilai batas error $=0,0012$ merupakan yang terbaik karena menghasilkan MSE dan MAPE terkecil pada tahap pengujian. Pada Gambar 6 merupakan grafik hasil pengujian pengaruh nilai batas error pada fungsi aktivasi ReLU - Linear.

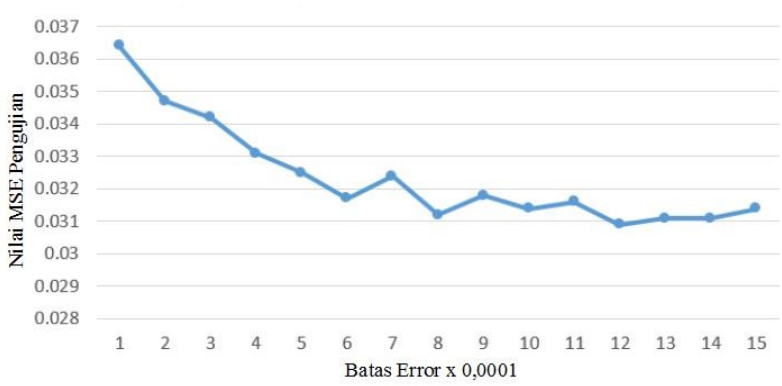

Gambar 6. Grafik hasil pengujian pengaruh nilai batas error dengan fungsi aktivasi ReLU - Linear.

\subsubsection{Validasi Backpropagation}

Pada tahap ini dilakukan peramalan data pada pada tahun 2018 dengan menggunakan bobot-bobot dengan menggunakan variabel terbaik berdasarkan hasil pengujian sistem yang telah dilakukan dengan menggunakan fungsi aktivasi ReLU - Linear. Pada Tabel IX merupakan perbandingan hasil validasi dengan menggunakan fungsi aktivasi ReLU - Linear dan fungsi aktivasi Sigmoid Biner yang sudah didapatkan sebelumnya pada Tabel V.

TABEL IX PERBANDINGAN HASIL VALIDASI DENGAN MENGgUNAKAN FUNGSI AKTIVASI RELU - LINEAR DAN SIGMOID

\begin{tabular}{|l|l|l|l|}
\hline No & $\begin{array}{l}\text { Data Input } \\
2018\end{array}$ & Sigmoid Biner & ReLU - Linear \\
\hline 1 & 55.623 .525 & 185.620 .016 & 147.221 .120 \\
\hline 2 & 49.500 & -18.639 .762 & 35.416 .868 \\
\hline 3 & 37.925 .880 & 77.668 .640 & 80.769 .896 \\
\hline 4 & 40.510 .456 & 169.522 .848 & 170.257 .168 \\
\hline 5 & 41.392 .078 & 35.958 .744 & 55.815 .640 \\
\hline 6 & 73.611 .411 & 137.864 .880 & 175.732 .528 \\
\hline 7 & 36.691 .259 & 219.132 .336 & 123.330 .320 \\
\hline 8 & 27.526 .174 & -15.101 .917 & 85.696 .888 \\
\hline 9 & 39.206 .347 & 84.789 .128 & 43.512 .856 \\
\hline 10 & 733.763 & 179.705 .168 & 175.836 .704 \\
\hline 11 & 29.533 .386 & 26.020 .544 & 85.139 .672 \\
\hline 12 & 29.452 .168 & 256.743 .264 & 99.765 .592 \\
\hline
\end{tabular}

Berdasarkan Tabel IX bisa dilihat bahwa hasil validasi dengan menggunakan fungsi aktivasi ReLU Linear menghasilkan hasil peramalan yang bernilai positif semua sedangkan hasil peramalan dengan menggunakan fungsi aktivasi Sigmoid Biner terdapat beberapa hasil peramalan yang bernilai negatif. Berdasarkan hal tersebut, maka fungsi aktivasi ReLU Linear lebih bagus untuk digunakan pada kasus peramalan jumlah nilai ekspor di provinsi NTB dibandingkan dengan menggunakan fungsi aktivasi Sigmoid Biner. Pada Gambar 7 merupakan grafik perbandingan hasil validasi dengan menggunakan 
fungsi aktivasi ReLU - Linear dan fungsi aktivasi Sigmoid Biner.

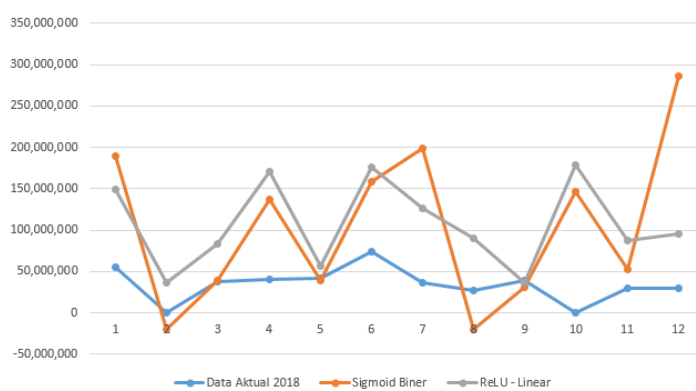

Gambar 7. Grafik perbandingan hasil validasi fungsi aktivasi Sigmoid Biner dengan ReLU - Linear

\subsection{Peramalan}

Pada tahap peramalan ini dilakukan dengan dua skenario yaitu meramalkan jumlah nilai ekspor di provinsi NTB dan meramalkan jumlah nilai ekspor per komoditi. Fungsi aktivasi yang digunakan adalah fungsi aktivasi Sigmoid Biner dan fungsi aktivasi ReLU - Linear. Fungsi aktivasi Sigmoid Biner tetap digunakan meskipun menghasilkan hasil validasi yang bernilai negatif dengan tujuan untuk membandingkan pola data hasil peramalan jumlah nilai ekspor di provinsi NTB dengan menggunakan fungsi aktivasi Sigmoid Biner dan ReLU - Linear. Variabel yang digunakan masing - masing fungsi aktivasi adalah variabel yang dihasilkan berdasarkan pengujian sistem yang telah dilakukan dengan menggunakan masing - masing fungsi aktivasi.

\subsubsection{Permalan Jumlah Nilai Ekspor di Provinsi NTB}

Pada skenario peramalan ini akan diramalkan jumlah nilai ekspor di provinsi NTB pada tahun 2019 dengan menggunakan data input pada tahun 2018 dengan menggunakan fungsi aktivasi Sigmoid Biner dan ReLU - Linear. Pada Tabel X merupakan hasil peramalan jumlah nilai ekspor pada tahun 2019.

Berdasarkan Tabel $\mathrm{X}$ bisa dilihat bahwa pada fungsi aktivasi Sigmoid Biner menghasilkan hasil peramalan yang berniliai negatif. Penyebab hasil peramalan yang bernilai negatif ini sudah dijelaskan pada tahap validasi dengan menggunakan fungsi aktivasi Sigmoid Biner. Pada Gambar 8 merupakan grafik hasil peramalan jumlah nilai ekspor di provinsi NTB pada tahun 2019 sesuai dengan Tabel $X$.

\subsubsection{Peramalan Jumlah Nilai Ekspor Per Komoditi}

Pada skenario peramalan ini dilakukan dengan menggunakan komoditi Gerabah, Kerajinan Buah Kering, Mutiara dan Konsentrat Tembaga. Komoditi tersebut digunakan pada skenario ini karena data jumlah nilai ekspor komoditi tersebut ada setiap tahunnya. Vairabel - variabel yang digunakan adalah variabel yang terbaik berdasarkan hasil pengujian sistem masing - masing komoditi, karena jika menggunakan variabel - variabel berdasarkan hasil pengujian sistem pada skenario meramalkan jumlah nilai ekspor total belum tentu bagus jika diterapkan pada skenario peramlan jumlah nilai ekspor per komoditi ini. Pada Tabel XI merupakan variabel terbaik hasil pengujian sistem per komoditi dengan fungsi aktivasi Sigmoid Biner dan pada Tabel XII merupakan variabel terbaik hasil pengujian sistem dengan menggunakan fungsi aktivasi ReLU - Linear.

TABEL X. HASIL PERAMALAN JUMLAH NILAI EKSPOR DI PROVINSI NTB PADA TAHUN 2019.

\begin{tabular}{|l|l|l|l|}
\hline No & $\begin{array}{c}\text { Data Aktural } \\
2018\end{array}$ & $\begin{array}{c}\text { Peram. 2019 } \\
\text { Sigmoid Biner }\end{array}$ & $\begin{array}{c}\text { Peram. 2019 } \\
\text { ReLU - Linear }\end{array}$ \\
\hline 1 & 55.623 .525 & 190.859 .632 & 222.144 .048 \\
\hline 2 & 49.500 & -11.642 .485 & 67.473 .528 \\
\hline 3 & 37.925 .880 & 96.318 .288 & 20.163 .722 \\
\hline 4 & 40.510 .456 & 46.288 .328 & 176.782 .112 \\
\hline 5 & 41.392 .078 & 39.141 .232 & 108.551 .848 \\
\hline 6 & 73.611 .411 & 334.063 .456 & 217.359 .584 \\
\hline 7 & 36.691 .259 & 203.145 .584 & 155.091 .504 \\
\hline 8 & 27.526 .174 & 58.803 .016 & 129.791 .768 \\
\hline 9 & 39.206 .347 & 349.832 .224 & 43.927 .732 \\
\hline 10 & 733.763 & 292.650 .752 & 4.587 .466 \\
\hline 11 & 29.533 .386 & 23.026 .430 & 300.569 .728 \\
\hline 12 & 29.452 .168 & 216.622 .864 & 147.184 .752 \\
\hline
\end{tabular}

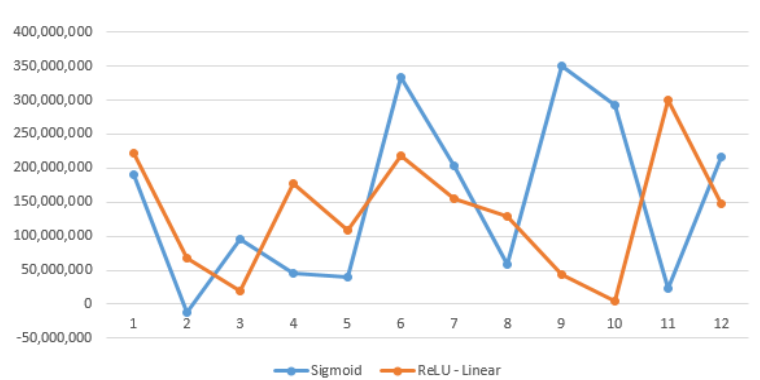

Gambar 8. Grafik hasil peramalan jumlah nilai ekspor di provinsi NTB pada tahun 2019.

TABEL XI. VARIABEL Terbaik Hasil PengujIAN Sistem PeR KOMODITI DENGAN FUNGSI AKTIVASI SIGMOID BINER

\begin{tabular}{|l|l|l|l|l|}
\hline No & Komoditi & $\begin{array}{l}\text { Ars. } \\
\text { Jaringan }\end{array}$ & $\begin{array}{l}\text { Learning } \\
\text { Rate }\end{array}$ & $\begin{array}{l}\text { Batas } \\
\text { Error }\end{array}$ \\
\hline 1 & Gerabah & $12-4-1$ & 0,3 & 0,0003 \\
\hline 2 & K. B. Kering & $12-4-1$ & 0,3 & 0,0002 \\
\hline 3 & Mutiara & $12-4-1$ & 0,3 & 0,0002 \\
\hline 4 & $\begin{array}{l}\text { Konsentrat } \\
\text { Tembaga }\end{array}$ & $12-4-1$ & 0,3 & 0,0015 \\
\hline
\end{tabular}


TABEL XII. VARIABEL TERBAIK HASIL PENGUJIAN SISTEM PER KOMODITI DENGAN FUNGSI AKTIVASI RELU - LINEAR

\begin{tabular}{|l|l|l|l|l|}
\hline No & Komoditi & $\begin{array}{l}\text { Ars. } \\
\text { Jaringan }\end{array}$ & $\begin{array}{l}\text { Learning } \\
\text { Rate }\end{array}$ & $\begin{array}{l}\text { Batas } \\
\text { Error }\end{array}$ \\
\hline 1 & Gerabah & $12-25-1$ & 0,1 & 0,0002 \\
\hline 2 & $\begin{array}{l}\text { K. B. } \\
\text { Kering }\end{array}$ & $12-20-1$ & 0,1 & 0,0002 \\
\hline 3 & Mutiara & $12-25-1$ & 0,1 & 0,0002 \\
\hline 4 & $\begin{array}{l}\text { Konsentrat } \\
\text { Tembaga }\end{array}$ & $12-5-1$ & 0,1 & 0,0012 \\
\hline
\end{tabular}

Selanjutnya pada Tabel XIII merupakan hasil peramalan per komoditi dengan menggunakan fungsi aktivasi Sigmoid Biner dan pada Tabel XIV merupakan hasil peramalan dengan menggunakan fungsi aktivasi ReLU - Linear.

TABEL XIII. Hasil PERAMALAN NILAI EKSPOR PER KOMODITI PADA TAHUN 2019 DENGAN FUNGSI AKTIVASI SIGMOID BINER

\begin{tabular}{|l|l|l|l|l|}
\hline No & $\begin{array}{l}\text { Gerab } \\
\text { ah }\end{array}$ & $\begin{array}{l}\text { K. B. } \\
\text { Kering }\end{array}$ & Mutiara & K.Tembaga \\
\hline 1 & 18.723 & 8.110 & -55.993 & 165.154 .736 \\
\hline 2 & 25.811 & 970 & -92.432 & 129.919 .280 \\
\hline 3 & 31.227 & 4.208 & -62.385 & 70.734 .136 \\
\hline 4 & 31.434 & 22.709 & -35.237 & 173.811 .616 \\
\hline 5 & 24.774 & 22.197 & 44.039 & 242.488 .976 \\
\hline 6 & 15.778 & 16.959 & 198.910 & 309.076 .384 \\
\hline 7 & 10.903 & 18.304 & 122.432 & 83.368 .928 \\
\hline 8 & 10.592 & 42.709 & 68.168 & 149.965 .712 \\
\hline 9 & 13.656 & 52.289 & -26.716 & 344.901 .536 \\
\hline 10 & 14.088 & 23.362 & -50.408 & 42.881 .688 \\
\hline 11 & 4.766 & 14.936 & 366.867 & 69.247 .968 \\
\hline 12 & 9.062 & 21.194 & 962.188 & 162.349 .648 \\
\hline
\end{tabular}

TABEL XIV. HASIL PERAMALAN NILAI EKSPOR PER KOMODITI PADA TAHUN 2019 DENGAN FUNGSI AKTIVASI RELU - LINEAR

\begin{tabular}{|l|l|l|l|l|}
\hline No & $\begin{array}{l}\text { Gerab } \\
\text { ah }\end{array}$ & $\begin{array}{l}\text { K. B. } \\
\text { Kering }\end{array}$ & Mutiara & K.Tembaga \\
\hline 1 & 13.765 & 8.047 & -189.743 & 165.154 .736 \\
\hline 2 & 11.439 & 6.696 & -205.499 & 129.919 .280 \\
\hline 3 & 19.018 & 9.018 & 152.871 & 70.734 .136 \\
\hline 4 & 17.769 & 23.719 & -297.034 & 173.811 .616 \\
\hline 5 & 15.605 & 19.209 & -691.810 & 242.488 .976 \\
\hline 6 & 11.554 & 9.505 & -522.058 & 309.076 .384 \\
\hline 7 & 4.399 & 11.034 & 62.080 & 83.368 .928 \\
\hline 8 & 6.224 & 50.030 & -432.378 & 149.965 .712 \\
\hline 9 & 12.040 & 73.959 & -1.591 .301 & 344.901 .536 \\
\hline 10 & 14.149 & 24.016 & -2.055 .340 & 42.881 .688 \\
\hline 11 & 22.970 & 19.032 & -422.365 & 69.247 .968 \\
\hline 12 & 12.488 & 24.806 & -815.755 & 162.349 .648 \\
\hline
\end{tabular}

Berdasarkan hasil peramalan pada Tabel XI dan Tabel XII bisa dilihat bahwa hasil peramalan jumlah nilai ekspor komoditi Mutiara untuk masing - masing fungsi aktivasi sama - sama menghasilkan nilai negatif. Hal ini dikarena pola data jumlah nilai ekspor komoditi Mutiara sangat tidak stabil sehingga dapat menghasilkan hasil peramalan yang bernilai negatif. Pada Gambar 9 merupakan grafik pola data nilai ekspor mutiara yang menyebabkan hasil peramalan bernilai negatif.

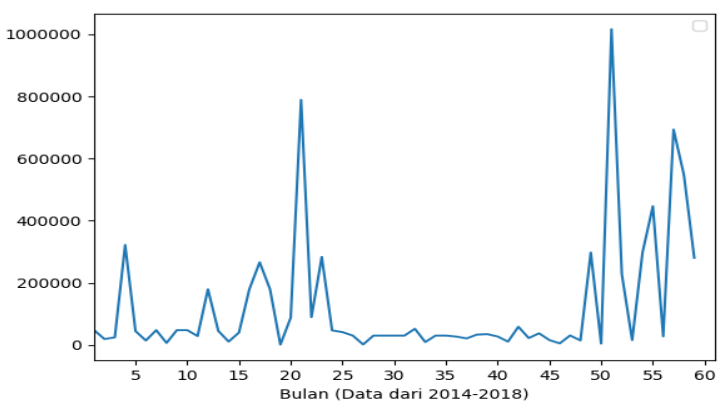

Gambar 9. Pola data nilai ekspor komoditi Mutiara.

\section{Kesimpulan dan SARAN}

\subsection{Kesimpulan}

Berdasarkan hasil pengujian sistem dan analisis penelitian yang dilakukan terhadap studi kasus peramalan jumlah nilai ekspor di provinsi NTB dengan algoritma Jaringan Saraf Tiruan metode Backpropagation maka dapat ditarik kesimpulan sebagai berikut :

1. Arsitektur jaringan $12-4-1$, nilai learning rate $=0,3$ dan batas error $=0,0015$ merupakan yang terbaik pada pengujian sistem dengan menggunakan fungsi aktivasi Sigmoid Biner karena menghasilkan nilai MSE sebesar 0,0161 dan MAPE sebesar $30,53 \%$, terkecil pada tahap pengujian.

2. Arsitektur jaringan $12-5-1$, nilai learning rate $=0,1$ dan batas error $=0,0012$ merupakan yang terbaik pada pengujian sistem dengan menggunakan fungsi aktivasi ReLU pada hidden layer dan Linear pada output layer karena menghasilkan nilai MSE sebesar 0,0309 dan MAPE sebesar 53,04\%, terkecil pada tahap pengujian.

3. Jumlah neuron pada hidden layer dapat mempengaruhi keakurasian hasil peramalan. Semakin banyak jumlah neuron hidden layer yang digunakan belum tentu dapat meningkatkan akurasi hasil peramalan.

4. Penerapan algoritma jaringan saraf tiruan metode backpropagation pada penelitian ini kurang cocok 
digunakan karena pola data jumlah nilai ekspor di provinsi NTB sangat tidak stabil sehingga nilai MAPE yang dihasilkan pada pengujian sistem tidak ada yang bernilai lebih kecil dari 20\%. Menurut Zainun [11], nilai MAPE yang mempunyai kinerja bagus berada diantara $10 \%$ - 20\% sedangkan untuk yang bekinerja sangat bagus berada dibawah $10 \%$.

\subsection{Saran}

Berdasarkan hasil penelitian yang telah dilakukan maka terdapat saran sebagai berikut jika ingin menerapkan algoritma Jaringan Saraf Tiruan metode Backpropagation kedalam suatu studi kasus :

1. Sebaiknya diuji coba lagi untuk menggunakan jumlah neuron pada hidden layer mulai dari yang sedikit hingga banyak lalu bandingkan mana yang terbaik.

2. Jika menggunakan fungsi aktivasi Sigmoid Biner sebaiknya uji dulu nilai learning rate yang akan digunakan, jangan gunakan yang terlalu besar karena dapat menghasilkan bobot yang kurang teliti meskipun dapat mempercepat proses pelatihan, sedangkan jika menggunakan fungsi aktivasi ReLU - Linear jangan gunakan learning rate terlalu besar karena dapat menyebabkan dying RELU.

\section{DAFTAR PUSTAKA}

[1] T. Rauf, "Info Publik," 2018. [Daring]. Tersedia pada : http://infopublik.id/read/280102/nilai-ekspor-ntbperiode-juni-2018-naik.html\#. [Diakses : 30-Jan2019].

[2] B. Siswoyo, "Analisis dan Penerapan Teknologi Jaringan Saraf Tiruan pada Model Peramalan Industri Perbankan," JATI : Jurnal Teknologi dan Informasi UNIKOM, vol. 5, no. 4, hal. 33-46, 2014.
[3] J. R. Saragih, M. B. S. Saragih, dan A. Wanto, "Analisis Algoritma Backpropagation dalam Prediksi Nilai Ekspor (Juta USD)," Jurnal Pendidikan Teknologi dan Kejuruan, vol. 15, no. 2, hal. 254-264, 2018.

[4] D. P. Anggriningrum, P. Hendikawati, dan Z. Abidin, "Perbandingan Prediksi Harga Saham dengan Menggunakan Jaringan Syaraf Tiruan Backpropagation dan ARIMA," Unnes Journal of Mathematics, vol. 2, no. 2, hal. 105-109, 2013.

[5] I. P. Sutawinaya, I. N. G. A. Astawa, dan N. K. D. Hariyanti, "Perbandingan Metode Jaringan Saraf Tiruan pada Peramalan Curah Hujan," Jurnal Logic, vol. 17, no. 2, hal. 92-97, 2017.

[6] J. J. Siang, Jaringan Syaraf Tiruan dan Pemrogramannya Menggunakan MATLAB, Jakarta: Andi, 2009.

[7] M. N. D. Sawitri, I. W. Sumarjaya, dan N. K. T. Tastrawati, "Peramalan Menggunakan Metode Backpropagation Neural Network," E-Jurnal Matematika, vol. 7, no. 3, hal. 264-270, 2018.

[8] R. J. Hyndman, dan A. B. Koehler, "Another Look at Measures of Forecast Accuracy," International Journal of Forecasting, vol. 22, hal. 679-688, 2006.

[9] C. F. Wang, "Toward Data Science," 2019. [Daring]. Tersedia pada https://towardsdatascience.com/the-vanishinggradient-problem-69bf08b15484. [Diakses : 7-Jul2019]

[10] D. Liu, "Medium," 2017. [Daring]. Tersedia pada : https://medium.com/@danqing/a-practicalguide-to-relu-b83ca804f1f7. [Diakses : 7-Jul2019]

[11] N. Y. B. Zainun, I. A. Rahman, dan M. Eftekhari, "Forecast Low-Cost Housing Demand in Johor Bahru, Malaysia Using Artficial Neural Network (ANN)," Journal of Mathematics Research, vol. 2, no. 1, hal. 14-19, 2010. 